\title{
Body Mass Index, Stress, and Dietary Habits of Women in their early 20s and late 20s
}

\author{
Jung-Soon Han \\ Research Institute of Human Ecology, College of Education, Korea University, Seoul, Korea
}

Corresponding author: Jung-Soon Han, Research Institute of Human Ecology, Korea University, 145 Anam-ro, Seongbukgu, Seoul 02841, Korea

Tel.: +82 232901672

Email: yohwa0960@korea.ac.kr

Received June 26, 2019

Revised August 20, 2019

Accepted September 3, 2019

Published September 30, 2019

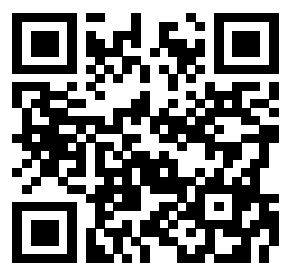

\begin{abstract}
Purpose: The educational and professional demands of women in their 20 s often lead to irregular eating habits and unbalanced diets. The present study investigated the relationships among body mass index (BMI), stress, and dietary habits of women in their early 20 s and late 20 s and suggests the importance of balanced dietary habits. Methods: Total 327 women, 160 in their early 20s and 167 in their late 20s, in Seoul and Gyeonggi, were enrolled. A questionnaires survey of their BMI, eating habits, and general characteristics was performed. The responses in the two groups were compared using $t$-test, frequency analysis, and simple regression. Results: The mean BMI of early 20 s women $\left(19 \mathrm{~kg} / \mathrm{m}^{2}\right)$ indicated a normal body weight and late 20 s women $\left(23 \mathrm{~kg} / \mathrm{m}^{2}\right)$ indicated overweight. There was no difference in the sleeping time, walking, and free time of the two groups. Women in their early 20s, were the most stressed by their academic work and those in their late 20 s by personal relations. For fitness, women in their early 20 s focused on their diet, while those in their late 20s used exercise therapy. Women in their 20s were interested in acquiring nutritional knowledge; however, they did not implement it. Women in their early 20 s were less likely to eat breakfast than women in their late 20s. Early 20 s women significantly ate more meat, fish, tofu and soybean products, dairy products, seaweeds, vegetables, and fruits that are rich in antioxdiants than late 20 s women. Conclusion: Healthy dietary habits that involve balanced consumption of various foods are important, and appropriate dietary education is necessary for women in their 20s.
\end{abstract}

Keywords: BMI, Stress, Dietary habits, Antioxidant, Dietary education

\section{Introduction}

우리나라는 비약적 경제발전과 과학·의료기술발달에 의해 생활 수준이 향상되고, 식품산업의 발달로 각종 가공식품과 편의식품이 개발되어 식생활의 편리함을 제공하고 있으나, 간편 인스턴트 식품 의 상용화 등의 식습관은 고지방·고열량·단순당 함량이 많은 식품 의 섭취 증가로 이어지고(Kim et al., 2018a) 생활의 편리함에 따 라 운동량은 감소하여 과체중과 비만이 급증하여 2016년 성인 비 만율이 42.3\%에 이르고 있다(Korea Health Statistics, 2016). 이 러한 비만은 체내에 체지방이 과잉으로 축적된 것으로 당뇨병, 고 혈압, 동맥경화증, 심근경색, 뇌졸중 등 각종 대사질환의 원인이 되고 있다(Chukir et al., 2018; Murphy et al., 2018; Piché et al., 2018; Reho \& Rahmouni, 2017). 비만은 체중을 신장 $\left(\mathrm{m}^{2}\right)$ 으
로 나눈 체질량지수(body mass index, BMI)로 분류할 때 23.0$24.9 \mathrm{~kg} / \mathrm{m}^{2}$ 과체중, $25.0 \mathrm{~kg} / \mathrm{m}^{2}$ 이상을 비만으로 정의하며 가장 보편적으로 사용되고 있다(World Health Organization Regional Office for the Western Pacific, 2000). 20대 여성은 학업과 취업 등 여러 가지 스트레스를 많이 받는 시기로 장래에 대한 불안 등 심 리적 부담이 많은데 비해 스트레스에 대처관리 뿐 아니라 식습관 등도 확고하게 형성되어 있지 않은 경우가 많아 결식, 편식, 다이어 트 등은 영양불균형을 유발하고 이러한 식생활이 지속되면 건강에 위해가 될 수 있다(Hwang et al., 2009). 식생활 습관은 개인의 어 릴 때부터 지속한 식생활양식으로 집단의 구성원에 의해 공유되고 있는 식생활의 내용이다(Shim et al., 2013). 바른 식습관은 건강 을 유지하는데 필요한 영양소가 함유된 식품을 다양하고 적절하게 
섭취하여 일생 동안 지속적으로 실천하는 것이다. 매일의 식생활 이 바람직하면 건강한 삶을 유지하나 불건전한 식생활은 신체기능 을 저하시켜 각종 질병 발생 위험이 증가되어 건강에 위해가 된다 (Han \& Kim, 2019). 20대 전반 여성들의 식습관 중 가장 문제가 되는 것은 영양섭취 부족이라고 하며, 원인으로는 사회적으로 마른 체형을 선호하고 스스로의 신체적인 만족을 위해 무리한 식사제한 이나 체중조절 때문이라고 하여(Seo et al., 2016), 20대 여성의 식 습관은 사회에서 기대하는 여성의 미에 대한 인식 및 요구로 다이 어트나 체중에 의해 많은 영향을 받는 것을 알 수 있다(Lee et al., 2013). 20대 여성들의 식습관에 대한 연구는 대부분이 주로 여대생 을 대상으로 한 영양소 섭취상태 조사나 스트레스와의 연관관계 등 이다(Kim \& Nam, 2010; Lee et al., 2013). 그러나 20대도 여성 들이 많은 관심을 가지고 있는 체중조절의 원인을 제공하는 비만의 기준이 되는 체질량지수와 스트레스, 20 대 전·후반의 식생활, 식습 관과 생활습관은 다를 것이라고 예측되나 이에 대한 연구는 없다. 또한 많은 매체들을 통해 각종 영양지식은 범람하고 있고 알고 있 는 경우는 많으나 이를 생활 속에서 실천하고 지속적으로 유지하는 것은 더욱 어려운 일이다. 이에 본 연구는 20 대 여성을 20 대 전반 과 20 대 후반으로 나누어 체질량지수, 스트레스 원인, 생활습관과 식생활 및 영양지식에 대한 인지와 실천여부 등을 조사하여 향후 20 대 여성들의 바람직한 식생활습관을 형성하고 지속하기 위한 식 생활교육 프로그램 개발 등의 기초자료로 제공하고자 수행되었다.

\section{Methods}

\section{1. 연구대상 및 조사}

서울과 경기지역에 소재한 20대 여성 350명을 대상으로 2018년 9월부터 11월까지 설문조사를 실시하여 부정확한 응답지를 제외 한 327 개를 분석에 사용하였다. 본 연구에 사용된 설문 내용은 선 행연구 Kim et al. (2018a)의 방법을 참조하여 예비조사를 거처 수 정 보완한 설문지로 체질량지수 산출 위한 신장, 체중에 관한 2 문 항, 생활습관 관련 4문항, 스트레스에 관한 8문항, 다이어트 경험 유무, 다이어트 방법에 관한 4 문항, 영양지식 인지 및 실천에 관한 3 문항, 식생활 관련 문항 9 문항으로 구성되었다. 식생활에 대한 내 용은 규칙적인 식생활, 균형 잡힌 식생활로 점수는 전혀 그렇지 않 다(1점), 그렇지 않다(2점), 보통이다(3점), 그렇다(4점), 매우 그렇
다(5점)으로 하였다.

\section{2. 통계분석}

조사된 모든 자료의 통계처리는 IBM SPSS Statistics 23 program을 사용하여 분석하였으며 통계적 유의수준 $(p)$ 은 0.05 로 설정하였다.

연구대상자의 특성은 빈도분석을 통하여 살펴보았으며 20 대 전 반과 후반의 각각의 요인별 차이를 보기 위해 $t$-test를 하였다. 요 인들이 조사도구로서의 타당성 확인은 요인분석을 하였고 문항간 의 신뢰성 검증은 크론바하의 알파(Cronbach's $\alpha$ )계수를 산출하여 살펴보았다.

\section{Results and Discussion}

\section{20대 전반과 20대 후반여성의 체질량지수}

설문에 응한 응답자수는 20 대 전반 여성 160 명의 평균 연령 은 22.31 세, 평균 신장은 $164.88 \mathrm{~cm}$, 평균 체중은 $52.22 \mathrm{~kg}$ 이었 다. 20 대 후반 여성 167 명의 평균 연령은 27.33 세, 평균 신장은 $156.46 \mathrm{~cm}$, 평균 체중은 $57.38 \mathrm{~kg}$ 이었다. 체질량지수는 비만 판 정의 지표로 체지방과 상관관계가 높은 체격지수로서 weight $(\mathrm{kg}) /$ height $\left(\mathrm{m}^{2}\right)$ 의 공식에 의해 계산하였다. 대한비만학회(Korean Society for the Study of Obesity 2000)에서 채택한 아시아태평 양 지역 지침에 따라 체질량 지수 $18.5 \mathrm{~kg} / \mathrm{m}^{2}$ 미만을 저체중군, $18.5-22.9 \mathrm{~kg} / \mathrm{m}^{2}$ 를 정상 체중군, $23-24.9 \mathrm{~kg} / \mathrm{m}^{2}$ 를 과체중군, $25.0 \mathrm{~kg} / \mathrm{m}^{2}$ 이상을 비만군으로 판정한 것을 기준으로 하였다. 이 를 기준으로 하였을 때 본 연구의 20 대 전반 여성의 체질량 지수 는 $19.21 \mathrm{~kg} / \mathrm{m}^{2}, 20$ 대 후반 $23.44 \mathrm{~kg} / \mathrm{m}^{2}$ 이었다(Table 1). 20 대 전반여성의 신장이 20 대 후반 여성보다 약 $8 \mathrm{~cm}$ 가량 크며, 체중 은 20 대 전반이 후반보다 약 $5 \mathrm{~kg}$ 가량 덜 나갔으며 20대 전반 여성 은 정상체중 범위를 보였고 20 대 후반 여성들은 과체중을 나타내 었다. 이는 Park (2009)의 경남지역 일부 여대생의 비만도에 따른 식습관, 체중 만족도 및 섭식 장애에 관한 연구에서 체질량지수가 $21.07 \mathrm{~kg} / \mathrm{m}^{2}$ 인 것 보다는 20 대 전반여성은 낮았고 20 대 후반 여 성은 높은 경향을 나타내었다. 이는 지역적인 차이는 있으나 대체 적으로 20 대 후반여성은 용모보다는 직업에 더 관심이 많은 경우가 흔하며, 20 대 전반 여성은 학생인 경우가 많고 여성의 용모를 최고

Table 1. Body mass index of women in their early $20 \mathrm{~s}$ and those in their late $20 \mathrm{~s}$

\begin{tabular}{|c|c|c|c|c|c|}
\hline Variables & $\mathrm{N}(\%)$ & Age & Height (cm) & Body weight (kg) & BMI $\left(\mathrm{kg} / \mathrm{m}^{2}\right)$ \\
\hline Early $20 \mathrm{~s}$ & $160(48.9)$ & $22.31 \pm 2.82^{1)}$ & $164.88 \pm 5.82$ & $52.22 \pm 10.22$ & $19.21 \pm 0.89$ \\
\hline Late 20 s & $167(51.1)$ & $27.33 \pm 2.84$ & $156.46 \pm 4.94$ & $57.38 \pm 7.92$ & $23.44 \pm 0.77$ \\
\hline Sum & 327 (100.0) & $24.31 \pm 2.82$ & $160.67 \pm 5.38$ & $54.80 \pm 9.08$ & $21.33 \pm 0.83$ \\
\hline
\end{tabular}

${ }^{1)}$ Mean \pm standard deviation; BMI, body mass index. 
가치로 여기는 사회문화적인 인식의 영향을 더 받게 되는 경향이 많아 외모에 조금 더 신경을 쓰고 체중에 관심을 많이 갖기 때문에 영향을 미친 것으로 사료된다(Hong \& Kim, 2007; Jang \& Shin, 2015).

\section{20대 전반 20대 후반 여성의 생활습관}

20 대 여성의 생활습관은 Table 2 와 같다. 수면시간은 20 대 전반 은 6-7 h 92명(60.0\%), $4 \mathrm{~h}$ 미만은 4명(1.3\%)이었다. 20대 후반은 6-7 h 94명(58.6\%), $4 \mathrm{~h}$ 미만 4명(1.3\%)으로 20대 전반과 20대 후반간의 수면시간에는 차이가 없는 것으로 나타났다. 걷는 시간 은 20대 전반과 20대 후반 모두 $30 \mathrm{~min}-1 \mathrm{~h}$ 미만이 57명(36.7\%), 50 명(30.6\%)이었으며, 2 h이상은 10 명(5.3\%), 8명(3.8\%)으로 20 대 전반과 20 대 후반의 걷는 시간에는 차이가 없는 것으로 나타났 다. 자유시간에는 TV시청, 컴퓨터게임 등을 한다 20 대 전반 112 명(75.7\%), 20대 후반 110 명(70.1\%), 친구들과 운동한다 20대 전 반 1 명 $(0.7 \%), 20$ 대 후반 3 명 $(1.9 \%)$ 으로 두 군간 차이는 없는 것 으로 나타났다. 운동 횟수는 20 대 전반의 경우 '거의 하지 않는다' 76 명(49.3\%), '주 1-2회' 운동한다 34명(21.3\%), '월 1-2회' 운동 한다. 22명(13.3\%), '주 3-4회' 운동한다. 20명(12.0\%), '주 6-7 회' 운동한다. 8명(4.0\%)순으로 나타났으며, 20 대 후반의 경우 '거 의 하지 않는다' 81 명(50.3\%), '주 1-2회' 22 명(12.7\%), '월 1-2회' 30 명(17.8\%), '주 3-4회' 31명(18.5\%), '주 6-7회' 3명(0.8\%)순으
로 나타나 유의적인 차이를 나타내었다. 이는 20 대 여성들이 운동 을 자주 하지 않는다는 다른 연구결과와(Jo \& Choi, 2010; Jang $\&$ Shin, 2015) 유사한 경향을 나타내었다. 운동은 생활에 활력을 줄 뿐 아니라 에너지 소비, 스트레스해소에도 중요한 역할을 하여 신체적 정신적 건강유지에 매우 필요하나 20대 전반여성이나 20대 후반 여성 모두 학업과 직장생활 등의 이유로 많이 하지 않는 것으 로 사료된다.

\section{20 대 전반 여성과 20 대 후반 여성의 스트레스 강도와 원인}

20 대 전반과 20 대 후반 여성의 스트레스 원인은 Table 3에서 보는 바와 같다. '매우 스트레스를 받는다' 20대 전반 여성 31명 (20.7\%), 20대 후반 43명(27.4\%), 스트레스를 '약간 받는다' 20 대 전반 109명(72.6\%), 20대 후반 여성 100명(63.7\%), 스트레스를 거의 받지 않는다. 20 대 전반 10 명 $(6.7 \%), 20$ 대 후반 14 명(8.9\%) 로 대부분의 20 대 전반여성, 20 대 후반 여성들 모두 스트레스를 받 고 있는 것으로 나타났으며, 20대 후반 여성들이 스트레스를 더 많 이 받고 있다고 하였으나 두 군간 유의적 차이는 나타나지 않았다. 스트레스를 받는 요인 중 가장 많은 것은 20 대 전반 여성은 학업 77 명 $(51.3 \%)$, 사람들 사이의 인간관계 35 명(23.3\%), 가족 내에서 의 문제 18 명(12.0\%)를 나타내었으나 20대 후반 여성은 사람들 사 이의 인간관계 51 명(32.5\%), 가족 내에서의 문제 31 명(19.7\%)로 두 군간 차이가 있는 것으로 나타났다 $(p<0.001)$. 이는 20 대 전반

Table 2. Life style and health-related factors women in their of early 20 s and those in their late 20 s

N (\%)

\begin{tabular}{|c|c|c|c|c|c|c|}
\hline Variables & & Early 20s & Late 20 s & $\mathrm{N}(\%)$ & $x^{2}$ & $p$ \\
\hline \multirow{4}{*}{$\begin{array}{l}\text { Sleep } \\
\text { duration }\end{array}$} & $\geq 4 \mathrm{~h}$ & $4(1.3)$ & $4(1.3)$ & $8(1.3)$ & \multirow{4}{*}{0.875} & \multirow{4}{*}{0.832} \\
\hline & $4-5 h$ & $17(10.0)$ & $23(13.4)$ & $40(11.7)$ & & \\
\hline & $6-7 \mathrm{~h}$ & $92(60.0)$ & $94(58.6)$ & $186(59.3)$ & & \\
\hline & $\geq 8 \mathrm{~h}$ & $45(28.7)$ & $44(26.8)$ & $89(27.7)$ & & \\
\hline \multirow{5}{*}{$\begin{array}{l}\text { Walking } \\
\text { duration }\end{array}$} & $10-20 \min$ & $17(10.0)$ & $29(17.2)$ & $44(13.7)$ & \multirow{5}{*}{4.742} & \multirow{5}{*}{0.315} \\
\hline & $20-30 \mathrm{~min}$ & $50(32.0)$ & $48(29.3)$ & $98(30.6)$ & & \\
\hline & $1 / 2-1 \mathrm{~h}$ & $57(36.7)$ & $50(30.6)$ & $107(33.6)$ & & \\
\hline & $1-2 \mathrm{~h}$ & $26(16.0)$ & 32 (19.1) & $58(17.6)$ & & \\
\hline & $\geq 2 \mathrm{~h}$ & $10(5.3)$ & $8(3.8)$ & $18(4.6)$ & & \\
\hline \multirow{5}{*}{$\begin{array}{l}\text { Free time } \\
\text { activity }\end{array}$} & Sleep & $24(16.0)$ & $28(17.8)$ & $52(16.9)$ & \multirow{5}{*}{1.534} & \multirow{5}{*}{0.821} \\
\hline & $\begin{array}{l}\text { TV view, computer } \\
\text { games etc. }\end{array}$ & $112(75.7)$ & $110(70.1)$ & $222(72.3)$ & & \\
\hline & Talk with friends & $11(7.3)$ & $13(8.3)$ & $24(7.8)$ & & \\
\hline & Exercise with friends & $1(0.7)$ & $3(1.9)$ & $4(1.3)$ & & \\
\hline & Etc & $2(1.3)$ & $110(70.1)$ & $5(1.6)$ & & \\
\hline \multirow{5}{*}{$\begin{array}{l}\text { Frequency of } \\
\text { exercise }\end{array}$} & 1-2 times/mon & $22(13.3)$ & $30(17.8)$ & $52(15.6)$ & \multirow{5}{*}{$10.258^{*}$} & \multirow{5}{*}{0.036} \\
\hline & 1-2 times/wk & $34(21.3)$ & $22(12.7)$ & $56(16.9)$ & & \\
\hline & 3-4 times/wk & $20(12.0)$ & $31(18.5)$ & 47 (15.3) & & \\
\hline & 6-7 times/wk & $8(4.0)$ & $3(0.8)$ & $11(2.3)$ & & \\
\hline & Little & 76 (49.3) & $81(50.3)$ & $157(49.8)$ & & \\
\hline
\end{tabular}

${ }^{*} p<0.05 ;{ }^{* *} p<0.01 ;{ }^{* * *} p<0.001$. 
의 여성의 경우 대학에 재학해 있는 여성이 많아 나타난 결과로 판 단되며, 20 대 후반 여성은 직장이나 사회에서 부딪치는 사람들과의 관계에서 오는 문제로 인한 스트레스를 받는 것으로 보인다. 본 연 구결과에서 20 대 전반 여성의 학업으로 인한 스트레스가 많은 경향 은 Kim et al. (2018b)의 20대 여대생이 학업에의 스트레스가 가장 크게 식생활에 영향을 미친다고 한 연구와 비슷한 경향을 나타내었 다.

\section{20 대 전반 여성과 20 대 후반 여성의 다이어트 경험과 영양지식 실천}

20 대 전반 여성과 20 대 후반 여성의 다이어트 경험과 영양지식 실천에 대한 내용은 Table 4에 제시하였다. 다이어트 경험 유무는
20 대 전반 여성 108명(65.3\%), 20대 후반 여성 131명(77.1\%)로 대부분의 20 대 여성은 모두 다이어트를 시도한 경험이 있는 것으로 나타났다. 다이어트 방법에 대한 질문에서는 20 대 전반여성은 식이 요법 50명(51.0\%), 운동요법 36명(36.7\%), 약물요법 4명(4.1\%), 비만 클리닉 치료가 3 명(3.1\%)로 나타났으나 20대 후반여성은 운 동요법이 57명(47.1\%), 식이요법이 48명(39.7\%), 약물요법 9명 (7.4\%), 비만 클리닉 치료가 2 명(1.7\%)로 나타나 다른 양상을 보여 주었다. 영양지식에 관심을 갖고 이를 식생활이나 실생활에서 적용 하는가에 대한 질문에서는 '영양지식에 관심이 없고 실천하지도 않 는다' 20대 전반 28명(18.7\%), 20대 후반 25명(15.9\%), '영양지식 에 대해 관심을 갖고 있으나 실천하지는 않는다'는 20대 전반 98 명 (65.3\%), 20대 후반 107 명(68.2\%), '영양지식에 관심을 가지고 있

Table 3. Stress intensity and causes of stress in the women in their early 20 s and those in their late 20 s

\begin{tabular}{|c|c|c|c|c|c|c|}
\hline Variables & & Early 20 s & Late 20s & Total & $x^{2}$ & $p$ \\
\hline \multirow{3}{*}{ Stress } & I am very stressed & $31(20.7)$ & $43(27.4)$ & $74(24.1)$ & \multirow{3}{*}{4.015} & \multirow{3}{*}{0.404} \\
\hline & $\begin{array}{l}\text { I get a little } \\
\text { stressed }\end{array}$ & $109(72.6)$ & $100(63.7)$ & $209(68.0)$ & & \\
\hline & $\begin{array}{l}\text { I do not get much } \\
\text { stress }\end{array}$ & $10(6.7)$ & $14(8.9)$ & $24(7.9)$ & & \\
\hline \multirow{5}{*}{ Stressor } & $\begin{array}{l}\text { Relationship with } \\
\text { people }\end{array}$ & 35 (23.3) & $51(32.5)$ & $86(28.0)$ & \multirow{5}{*}{$43.909^{* * *}$} & \multirow{5}{*}{0.000} \\
\hline & $\begin{array}{l}\text { Problems in the } \\
\text { family }\end{array}$ & $18(12.0)$ & $31(19.7)$ & $49(16.0)$ & & \\
\hline & Study & 77 (51.3) & $26(16.6)$ & 103 (33.6) & & \\
\hline & $\begin{array}{l}\text { Health and } \\
\text { disease }\end{array}$ & $5(3.3)$ & $15(9.6)$ & $20(6.5)$ & & \\
\hline & etc & 15 (10.0) & 34 (21.7) & 49 (16.0) & & \\
\hline
\end{tabular}

${ }^{*} p<0.05 ;{ }^{* *} p<0.01 ;{ }^{* * *} p<0.001$.

Table 4. Interest in healthy diet practices and implementation of nutrition knowledge in women in their early 20 s and those in their late 20s

\begin{tabular}{|c|c|c|c|c|c|c|}
\hline Variables & & Early 20s & Late 20 s & Total & $x^{2}$ & $p$ \\
\hline \multirow{2}{*}{$\begin{array}{l}\text { Interest in } \\
\text { healthy diet }\end{array}$} & Yes & $108(65.3)$ & 131 (77.1) & 239 (71.3) & \multirow{2}{*}{$5.168^{*}$} & \multirow{2}{*}{0.023} \\
\hline & No & 62 (34.7) & 46 (22.9) & $108(28.7)$ & & \\
\hline \multirow{5}{*}{$\begin{array}{l}\text { Practices } \\
\text { followed for } \\
\text { health }\end{array}$} & Exercise therapy & $36(36.7)$ & 57 (47.1) & $93(42.5)$ & \multirow{5}{*}{4.540} & \multirow{5}{*}{0.338} \\
\hline & Diet therapy & 50 (51.0) & $48(39.7)$ & $98(44.7)$ & & \\
\hline & Drug therapy & $4(4.1)$ & $9(7.4)$ & $13(5.9)$ & & \\
\hline & Clinic & $3(3.1)$ & $2(1.7)$ & $5(2.3)$ & & \\
\hline & Etc & $5(5.1)$ & $5(4.1)$ & $10(4.6)$ & & \\
\hline \multirow{3}{*}{$\begin{array}{l}\text { Interest and } \\
\text { implementation } \\
\text { of nutrition } \\
\text { knowledge }\end{array}$} & $\begin{array}{l}\text { I do not care about nutrition } \\
\text { knowledge and do not practice }\end{array}$ & $28(18.7)$ & 25 (15.9) & 53 (17.3) & \multirow{3}{*}{0.426} & \multirow{3}{*}{0.808} \\
\hline & $\begin{array}{l}\text { I am interest in nutrition knowledge } \\
\text { but not practice }\end{array}$ & 98 (65.3) & $107(68.2)$ & $205(66.8)$ & & \\
\hline & $\begin{array}{l}\text { I am interested in nutrition } \\
\text { knowledge and practice }\end{array}$ & $24(16.0)$ & 25 (15.9) & $49(16.0)$ & & \\
\hline Total & & 160 (100.0) & 167 (100.0) & $327(100.0)$ & & \\
\hline
\end{tabular}

${ }^{*} p<0.05 ;{ }^{* *} p<0.01 ;{ }^{* * *} p<0.001$. 
고 이를 식생활에 실천한다'가 20대 전반 24 명(16.0\%), 20 대 후반 25 명(15.9\%)를 나타내어 두 집단 모두 '영양지식에 관심을 가지고 는 있으나 실천하지는 않는다'로 답변하여 Seo et al. (2016)의 연 구결과와 비슷한 경향을 나타내었다. 이러한 연구결과는 매일의 식 생활에서 영양지식을 쉽고 지속적으로 실천하게 하는 영양교육이 나 식생활교육이 필요함을 시사한다고 생각된다.

\section{20대 전반과 20대 후반 여성의 식습관 및 식생활}

20 대 전반과 20 대 후반의 식습관 및 식생활은 Table 5 에 제시된 바와 같으며 조사 문항 간의 신뢰도를 나타내는 Cronbach's $\alpha$ 값은 0.759 를 나타내어 본 연구결과는 신뢰할 만하다고 할 수 있다. 20 대 전반은 '하루에 세끼 식사를 하며 매일 여러 가지 음식을 골고루 먹는다' 는 2.62점, 20대 후반 2.49점, '아침식사를 잘 챙겨먹는다' 는 2.80점, 2,56점으로 유의적인 차이가 나타나지 않았으나 20대 전반 여성이 20 대 후반여성보다는 하루 세끼 식사를 하며 아침식 사도 하는 것으로 나타났다. '하루에 8컵 정도의 물을 꾸준히 마신 다' 는 질문에서 20 대 전반은 2.38 점, 20 대 후반은 2.32 점 '육류(소 고기, 돼지고기, 닭고기), 어류(연어, 꽁치, 고등어 등), 난류(달걀, 오리 알, 메추리 알 등)을 하루에 한 번 이상 섭취한다'는 20 대 전반 3.27 점, 20 대 후반 3.15점으로 나타났다. '두부 및 콩 제품(비지, 순두부, 두유 등)을 자주 섭취한다'는 20대 전반 2.83점, 20 대 후 반 2.87점, '유제품(우유, 요구르트, 치즈 등)을 1 일 1회 이상 섭취 한다' 20 대 전반 2.89 점, 20 대 후반 2.82 점, '해조류(김, 미역, 다시 마 등)를 자주 섭취한다' 20 대 전반 2.74 점, 20 대 후반 2.73점, '채 소류, 과일류를 매일 섭취한다' 20대 전반 3.37점, 20 대 후반 3.08 점, '견과류(아몬드, 땅콩, 호두, 잣 등)를 자주 섭취한다' 20 대 전반 2.46점, 20 대 후반 2.36점으로 나타났다. 이는 Park (2009)의 연 구에서 정상 체중군이 과체중이나 저체중에 비해 과일 채소, 우유,
해조류 등을 섭취하고 짠 음식이나 화학조미료를 덜 섭취하며 단 음식과 기름진 음식도 많이 섭취하지 않는 긍정적인 식습관을 나타 내었으며, 편식을 하지 않고 스트레스도 덜 받는 다고 하여 본 연구 결과와 비슷한 경향을 나타내었다. 특히 아침식사의 중요성은 Lee et al. (2013)과 Shim et al. (2013)의 연구에서 아침 결식률이 높 을수록 비만하다고 한 결과에서도 강조되고 있어 아침식사를 꾸준 히 하는 식생활교육과 아침식사의 중요성 인식을 위한 지속적으로 실천할 수 있는 바람직한 영양교육과 식생활교육이 매우 필요함을 알 수 있었다. 본 연구에서 20 대 전반 여성들이 20 대 후반 여성들 에 비해 섬유소 함량이 높은 채소 과일 섭취가 많은 것은 바람직한 경향으로 판단된다. 또한 과일류의 섭취가 많은 군이 체중이 더 적 게 나가며 과일류의 섭취가 적은 군이 비만하였다고 하는 연구보고 (Kim, 2000; Lee, 2006)도 과일, 채소의 섭취가 건강에 미치는 긍 정적인 중요성을 뒷받침하는 결과로 사료된다.

\section{Conclusion}

이상의 결과 20 대 전반 여성은 정상체중범위에 있었으며 20 대 후반 여성은 과체중 범위에 있는 것으로 나타났으며, 스트레스는 20 대 전반 여성은 학업에서, 20 대 후반 여성은 대인관계에서 가장 많이 받고 있었다. 20대 전반 여성들이 후반 여성들보다 과일, 채 소 등 식이섬유소와 항산화 영양소가 많이 함유된 식품을 섭취하고 있는 것으로 나타났다. 또한 20 대 전반 여성이 아침식사를 거르지 않고 수분 섭취도 꾸준히 하는 것 등 규칙적인 식생활을 하여 식습 관이 긍정적인 것으로 나타났다. 특히 20대 여성들의 식생활과 식 습관은 여성 자신의 건강뿐 아니라 미래 한 가정을 구성하는 구성 원들의 식습관에도 영향을 미치게 되므로 균형 있는 식생활에 대한

Table 5. Score of the dietary behaviors and dietary habits

\begin{tabular}{|c|c|c|c|}
\hline Variables & $\begin{array}{c}\text { Early 20s } \\
(\mathrm{N}=160)\end{array}$ & $\begin{array}{l}\text { Late } 20 \mathrm{~s} \\
(\mathrm{~N}=167)\end{array}$ & $t$ \\
\hline Have three meals a day & $2.62 \pm 0.94$ & $2.49 \pm 0.87$ & 1.257 \\
\hline Have breakfast regularly & $2.80 \pm 1.36$ & $2.56 \pm 1.37$ & 1.539 \\
\hline Drink 8 cups of water a day & $2.38 \pm 0.99$ & $2.32 \pm 1.06$ & 0.470 \\
\hline At least once a day, eat meat, fish and eggs & $3.27 \pm 0.98$ & $3.15 \pm 1.03$ & 1.050 \\
\hline Tofu, soy milk, and soybean products are frequently consumed & $2.83 \pm 1.00$ & $2.87 \pm 0.97$ & -0.411 \\
\hline Take dairy products (milk, yogurt, cheese, etc.) more than one a day & $2.89 \pm 1.09$ & $2.82 \pm 1.04$ & 0.640 \\
\hline Seaweeds are often eaten & $2.74 \pm 0.92$ & $2.73 \pm 0.88$ & 0.135 \\
\hline Vegetables, and fruits daily & $3.37 \pm 0.91$ & $3.08 \pm 1.03$ & $2.614^{* * *}$ \\
\hline Nuts (almonds, peanuts, walnuts etc) are often eaten & $2.46 \pm 0.93$ & $2.36 \pm 0.96$ & 0.956 \\
\hline Mean \pm standard deviation & $2.82 \pm 0.59$ & $2.71 \pm 0.61$ & 1.599 \\
\hline
\end{tabular}

${ }^{* * *} p<0.001$. 
스스로의 인지와 식습관을 바르게 하고자 하는 노력이 필요하다고 판단된다. 또한 사회적 차원에서 지속적이고 꾸준히 실천할 수 있 는 바람직한 영양교육과 식생활교육의 필요성을 제시하는 결과로 사료된다.

\section{References}

Chukir T, Shukla AP, Saunders KH, Aronne し. Pharmacotherapy for obesity in individuals with type 2 diabetes. Expert Opinion Pharmacotherapy, 19: 223-31, 2018.

Han JS, Kim YK. Effects of a weight management program on body composition, and calcium, zinc, and iron intake in middle aged women with obesity. Asian Journal of Beauty and Cosmetology, 17: 15-24, 2019.

Hong JI, Kim JD. Health state of women's skin and relevant life style. Journal of the Korean Society of Cosmetology, 13: 964-975, 2007.

Hwang JY, Ru SY, Ryu HK, Park HJ, Kim WY. Socioeconomic factors relating to obesity and inadequate nutrient intake in women in low income families residing in Seoul. Journal of Nutrition and Health, 42: 171-182, 2009.

Jang JH, Shin KO. Study on body image perception, eating habits, obesity stress by BMI in female college students. Journal of Korean society Cosmetology, 21: 131-137, 2015.

Jo HJ, Choi MJ. Effects of dietary habits and nutrient intakes on skin condition of female university students. Journal of Nutrition and Health, 43: 233-245, 2010.

Kim A, Kim J, Kye S. Sugar-sweetened beverage consumption and influencing factors in Korean adolescents: based on the 2017 Korea youth risk behavior web-based survey. Journal of Nutrition and Health, 51: 465-479, 2018a.

Kim YJ, Kim B, Yoon JY, Joo N. Structural relations of dietary lifestyle and sugar intake according to stress from daily activities: focusing on female university students in Seoul. The East Asian Society of Dietary Life, 28: 156165, 2018b.

$\mathrm{Kim} \mathrm{KH}$. The relation between life stress and nutrient intake status in female university students. Journal of the Korean Society of Dietary Culture, 15: 387-397, 2000.
Kim YR, Nam MW. The effect of female universities student's beauty care on the stress. Asian Journal of Beauty and Cosmetology, 8: 263-273, 2010.

Korea Health Statistics (Korea Centers for Disease Control and Prevention, Korea National Health and Nutrition Examination Survey (KNHANES VII-1)), 2016.

Lee HM. Effect of stress, lifestyle, dietary habits and food preference on the sweet taste perception of the university female students. Korean Journal of Health Promotion, 6: 20-27, 2006.

Lee SE, Kim YH, Kim BH. A study on knowledge and action of female university student's skin health care. Journal of Korean Society of Cosmetology, 19: 732-738, 2013.

Murphy N, Jenab M, Gunter MJ. Adiposity and gastrointestinal cancers: epidemiology, mechanisms and future directions. Nature Reviews Gastroenterology \& Hepatology, 15: 659-670, 2018.

Park KA. Dietary habits, body weight satisfaction and eating disorders according to the body mass index of female university students in Kyungnam province. The East Asian Society of Dietary Life, 19: 891-908, 2009.

Piché ME, Poirier P, Lemieux I, Després JP. Overview of epidemiology and contribution of obesity and body fat distribution to cardiovascular disease: an update. Progress in Cardiovascular Diseases, 61: 103-13, 2018.

Reho JJ, Rahmouni K. Oxidative and inflammatory signals in obesity-associated vascular abnormalities. Clinical Science, 131: 1689-1700, 2017.

Seo JH, Ma H, Kim S, Kim J, Shin M, Yang YJ. Effects of the difference between actual body condition and body image perception on nutrient intake, weight control and mental health in Korean adults: based on the 5th Korea national health and nutrition examination survey. Journal of Nutrition and Health, 49: 153-164, 2016.

Shim JE, Yoon JH, Kim K, Paik HY. Association between picky eating behaviors and growth in preschool children. Journal of Nutrition and Health, 46: 418-426, 2013.

World Health Organization Regional Office for the Western Pacific. The Asia-Pacific perspective: redefining obesity and its treatment. Health Communications Australia, Sydney, pp15-18, 2000. 


\section{국문초록}

\section{0대 전반과 20대 후반 여성의 체질량지수, 스트레스와 식생활습관에 대한 연구}

한정순

고려대학교 사범대학 생활과학연구소, 서울, 한국

목적: 20 대 여성들은 학업과 일, 다이어트 등의 이유로 식습관이 불규칙해 영양불균형인 경우가 많다. 이에 본 연구는 20 대 전반 여 성과 20대 후반 여성의 체질량 지수, 스트레스 원인, 식생활습관을 조사하여 균형 있는 식생활을 지속적으로 실천할 수 있는 식생 활교육의 필요성과 중요성을 제시하고자 하였다. 방법: 서울과 경기지역에 거주하는 20 대 전반 여성 160 명, 20 대 후반 여성 167 명, 총 327 명을 대상으로 일반사항, 생활습관, 스트레스 원인과 강도, 영양지식에 대한 인지와 실천여부, 식생활과 식생활 습관에 대한 내용으로 설문조사를 하였다. 연구대상자의 특성은 빈도분석을 통하여 살펴보았으며 20 대 전반과 후반의 각각의 요인별 차이 를 보기 위해 $t$-test를 하였다. 요인들의 조사도구로서의 타당성 확인은 요인분석을 하였다. 결과: 체질량 지수는 20 대 전반 여성은 $19 \mathrm{~kg} / \mathrm{m}^{2}$ 으로 정상체중 범위였으며, 20 대 후반 여성은 $23 \mathrm{~kg} / \mathrm{m}^{2}$ 으로 과체중을 나타내었다. 20대 전반과 20대 후반간의 수면시간 과 걷는 시간은 차이가 없는 것으로 나타났다. 20 대 전반 여성은 학업에 의한 스트레스를 가장 많이 받고 있었으며, 20 대 후반 여성 은 대인관계에서 가장 스트레스를 많이 받는 것으로 나타났다. 20대 전·후반 여성 모두 다이어트 경험이 있으며 다이어트 방법으로 는 20대 전반여성은 식사요법, 20 대 후반여성은 운동요법이었다. 20대 전·후반 여성 모두 영양지식에 관심을 갖고 있으나 실생활에 서 실천하지는 않는 것으로 나타났다. 식생활 습관에서 20 대 전반 여성은 20 대 후반 여성보다 아침 결식이 적었다. 육류, 생선, 두 부 및 콩 제품, 유제품, 해조류 섭취와 항산화영양소가 많은 채소류, 과일류 섭취는 20 대 전반 여성이 20 대 후반 여성보다 유의적으 로 높게 나타났다. 견과류 섭취는 20 대 전반여성이 20 대 후반 여성보다 낮게 나타났다. 결론: 즉, 본 연구결과는 과일과 채소류 같 은 항산화식품 등 각종 식품을 골고루 섭취하는 식생활 습관이 중요하며, 지속적으로 실천할 수 있는 바람직한 식생활교육의 필요 성을 제시하는 것으로 사료된다.

핵심어: 체질량지수, 스트레스, 식생활습관, 항산화영양소, 식생활교육

\section{참고문헌}

김경희. 여대생의 생활 스트레스와 영양소 섭취 상태와의 관계. 한국식생활문화학회지, 15: 387-397, 2000.

김아영, 김진희, 계승희. 한국 청소년의 가당음료 섭취실태 및 영향요인. Journal of Nutrition and Health, 51: 465479, 2018.

김영란, 남미우. 여대생의 미용관심 요인이 스트레스에 미치는 영향. 아시안뷰티화장품학술지, 8: 263-273, 2010.

김유정, 김보람, 유지영, 주나미. 여대생의 생활스트레스 요인에 따른 식생활 유형과 당류 섭취 실태에 관한 구조적 관계 연구. 동아시아식생활학회지, 28: 156-165. 2018.

박경애. 경남 지역 일부 여대생의 비만도에 따른 식습관, 체중 만족도 및 섭식 장애에 관한 연구. 동아시아식생활학회지, 19: 891-908, 2009.

서지현, 마혜선, 김성희, 김지영, 신민서, 양윤정. 한국 성인의 체질량 지수에 따른 비만도와 주관적 체형인식 간의 차이가 영양소 섭취와 체중조절 및 정신건강에 미치는 영향. Journal of Nutrition and Health, 49: 153-164, 2016.

심재은, 윤지현, 김기준, 백희영. 유아기 까다로운 식습관과 성장상태 간의 연관성. Journal of Nutrition and Health, 46: 418-426, 2013.

이성은 김영희, 김배환. 여대생의 피부건강에 대한 지식수준이 관리행위에 미치는 영향. 한국미용학회지, 19: 732-738, 2013.

이홍미. 일부 여대생의 스트레스, 생활습관, 식습관 및 식품기호도가 단맛의 민감도와 선호도에 미치는 영향. 대한임상건 
강증진학회지, 6:20-27, 2006.

장재현, 신규옥. 여대생의 체질량지수(BMI)에 따른 체형인식, 식습관 및 비만스트레스에 관한 연구. 한국미용학회지, 21: 131-137, 2015.

조현주, 최미자. 여대생의 식습관과 영양소 섭취상태가 피부상태에 미치는 영향. Journal of Nutrition and Health, 43: 233-245, 2010.

한정순, 김유경. 체중관리 프로그램이 중년비만여성의 체성분과 칼슘, 아연, 철 섭취에 미치는 영향. 아시안뷰티화장품학 술지, 17: 15-24, 2019.

황지윤, 류성엽, 유한경, 박희정, 김화영, 서울지역 저소득층 여성의 비만 및 영양소 섭취 부족과 관련된 사회경제적 요인. Journal of Nutrition and Health, 42: 171-182, 2009.

홍진이, 김주덕. 여성의 피부건강상태 및 관련 생활행태의 연구. 한국미용학회지, 13: 964-975, 2007. 


\section{中文摘要}

\section{0岁早期和晚期妇女的体重指数，压力和饮食习惯研究}

韓正順

高丽大学生活科学研究所, 首尔, 韩国

目的: 20多岁的女性由于学业，工作和饮食习惯导致不正常的饮食习惯，往往营养不良。因此，本研究旨在通过 检查20岁早期和晚期女性的体重指数, 压力原因和强度以及饮食习惯, 提出饮食教育的必要性和重要性, 以持 续实现均衡饮食。方法: 首尔和京畿道地区的20岁早期的女性160名和20岁晚期的女性167名, 共对327名女性 针对一般知识, 生活习惯, 压力原因和强度, 营养知识的认知和实践与否, 饮食和饮食习惯等内容进行问卷调 查。通过频率分析检查研究对象的特征, 并进行 $t$ 检验以观察二十岁早期和晚期各因素之间的差异。进行因子分 析以确认因子作为研究工具的有效性。结果: 20 岁早期的女性 $\left(19 \mathrm{~kg} / \mathrm{m}^{2}\right)$ 的平均BMI表明体重正常, 20岁的 女性 $\left(23 \mathrm{~kg} / \mathrm{m}^{2}\right)$ 表示超重。两组的睡眠时间, 步行和空闲时间没有差异。20岁早期的女性受到学业上的压力 最大, 而20岁晚期的女性则受到个人关系的压力。对于健身, 20岁早期的女性专注于饮食, 而20岁晚期的女性 则使用运动疗法。20早期和晚期的女性对获取营养知识感兴趣; 但是, 他们没有实施它。20晚期的女性吃早餐 的可能性低于20岁早期的女性。20岁早期的女性对肉类，鱼类，豆腐和大豆制品，乳制品，海藻，含有大量抗 氧化营养素的蔬荣和水果摄入量显著高于20晚期的女性。20岁早期的女性坚果摄入量低于20岁晚期女性。结论: 涉及均衡食用各种食物的健康饮食习惯很重要，对20晚期的女性来说，必须进行适当的饮食教育。

关键词: 体重指数，压力，饮食习惯，抗氧化营养素，饮食教育 
